\title{
What can be Done about Massive Macroalgal Blooms?
}

\section{Mauro Lenzi*}

Lagoon Ecology and Aquaculture Laboratory (LEALab), OPL s.r.l., via G. Leopardi 9, 58015 Orbetello, Italy

\section{Introduction}

In the last 40 years, eutrophication of coastal waters has become a worldwide problem [1]. Massive development of fast growing opportunistic macroalgae with simultaneous disappearance of seagrass and alteration of food webs are the main consequences of eutrophication in shallow waters [2]. The consequences of eutrophication manifest in many coastal areas of the world, including estuaries, lagoons and vast areas of open sea [3-6].

These phenomena not only threaten coastal fisheries but also tourism, which for many countries has become a major resource. The situation is complex and not easy to solve. From many points of view it is like a snake biting its own tail. Indeed, the tourist boom of recent decades has led to overcrowding of coastal areas for several months of the year, overloading urban wastewater treatment plants.

The same is true of aquaculture, another major source of income, especially in southeast Asia where it is often conducted on a family scale. Aquaculture has environmental impacts (mangrove loss, collection of wild seed and broodstock, introduction of allochthonous species, spread of diseases, medications and waste release, ...), but is damaged by the water pollution it causes: pathogens, toxic catabolites, increased bacterial load, organic substances and suspended detritus promote disease in raised species, reducing their growth rate and raising management costs [7-9].

Lagoons and estuaries are highly productive fishing areas with high naturalistic and ecological value. They are where juveniles of many important commercial species grow (e.g. eels and mullet), as well as being transit areas for migratory water birds. The current eutrophic and hypertrophic conditions of many of these areas destroy their enormous productive potential and lead to the dominance of faciescharacterised by opportunistic macroalgae, which are known to proliferate on a massive scale and undergo sudden decay in summer. This in turn promotes the development of anoxigenic bacteria, release of toxic catabolites and fish die-off.

The problem is undeniably compounded by climate change, which favors almost uninterrupted growth of macro and microalgae when appropriately sustained by nutrient availability. A recent example: in 2014, summer temperatures were mild and never particularly hot at Orbetello (Tuscany, Italy), so that summer growth of algae in the lagoon did not cease. In autumn, temperatures were higher than the seasonal average and macroalgal vegetation continued to proliferate, rendering vain all attempts to contain it (unpubl. data).

The consequences of eutrophication can be expected to worsen in the years to come as a result of climate change, posing serious problems for ecosystem biodiversity and for coastal economies. It is therefore necessary to think up new ways to tackle these problems.

Much has been done to reduce inputs of nitrogen and phosphorus into water courses, lagoons and the sea, especially in the USA and EU. However, we are still far from reducing them enough to return waters to their original oligotrophic conditions, and this task is practically impossible considering the constant increase in world population, coastal overcrowding, civil wastewater inputs and industrial effluent reaching the sea via major rivers. Coastal areas, especially those with low water exchange, are already rich in nutrients that remain trapped in sediments and the biological lungs of various coastal ecosystems. For example, we estimate that superficial sediments (upper $3 \mathrm{~cm}$ ) of Orbetello lagoon contain enough nitrogen $(\mathrm{N})$ and phosphorus $(\mathrm{P})$ to sustain 8 (for $\mathrm{P}$ ) to 18 (for $\mathrm{N}$ ) times the already imposing masses of macroalgae produced annually [10].

Although attempts to reduce nutrient sources must continue, they cannot be the only measure taken. Effective systems for managing the consequences of eutrophication downstream are also necessary.

For years my lab has been studying the possibility of making the nutrient resources of superficial sediments (upper 3-5 cm) unavailable for algal proliferation by oxidizing inorganic detritus and mineralizing organic matter through resuspension of sediments in the water column [11]. Accumulations of organic matter cause anoxia of sediments, development of anaerobic mineralizers and nutrient release. On the other hand, a decrease in organic matter and a prevalence of oxidative status favor denitrification and orthophosphate sequestration by iron and manganese oxy-hydroxides and by calcareous concretions.

However, it is not easy to put these concepts into practice in an already impaired environment that develops macroalgal mats stretching for hundreds of hectares with densities exceeding $10 \mathrm{~kg} / \mathrm{m}^{3}$. To trigger the sediment control process, it is first necessary to dispose of the high-density macroalgal mat, otherwise the sediment, resuspended many times, loses part of its organic detritus but acquires more from the processes set in motion, in a continuum from decay of the algal underlayer while the overlayer continues to grow.

What can be done in such cases? Normally we harvest quantities of algae and remove them from the lagoon and marine systems [12-15], but in the absence of an enormous effort requiring economic resources unavailable today, we may only be removing a quantity equal to what grows again in the time it takes the boats to harvest it. Since we have not yet found an industrial use for these masses of ephemeral opportunistic macroalgae, once landed they create a disposal problem and a further increase in costs.

A solution that my lab has recently started to study is in situ demolition of the macroalgal mats. At the moment we use the boat propellers which have to pass repeatedly over areas of the vast mats. However, we will soon be using slashers like those used in agricultural fields and roadsides. Of course the plant fragments add to the detritus

*Corresponding author: Mauro Lenzi, Lagoon Ecology and Aquaculture Laboratory (LEALab), OPL s.r.l., via G. Leopardi 9, 58015 Orbetello, Italy, Tel:+39 3487 304274; E-mail: lealab2@hotmail.com

Received November 17, 2014; Accepted November 18, 2014; Published January 12, 2015

Citation: Lenzi M (2015) What can be Done about Massive Macroalgal Blooms? J Aquac Res Development 6: 292. doi:10.4172/2155-9546.1000292

Copyright: (c) 2015 Lenzi M. This is an open-access article distributed under the terms of the Creative Commons Attribution License, which permits unrestricted use, distribution, and reproduction in any medium, provided the original author and source are credited. 
on the bottom, where we intervene again setting in motion processes of "forced mineralization" by resuspension of sediment. This is possible in shallow water systems where resuspension can in the end control further plant development. We are unable to predict what the effect might be in the open sea, where massive blooms are sometimes favored by particular currents, but where we do not know what the fate could be of detritus from tens of thousands of tons of chopped up algae which cannot be mineralized artificially in deep water.

More attention and effort by researchers is needed in this sector. We need to find suitable equipment to demolish and chop up the mats, which may vary with the type of algae, and to consider the problems related to this new detritus and its transport and dispersal by currents and wind. Dispersal may vary enormously and detritus may have different effects on different systems depending on many variables. The formation of plant detritus could even promote the growth of detritivores and filter-feeders, also altering trophic webs in relatively distant areas. Greater dispersal could avoid dystrophic events like those occurring in areas where the macroalgae suddenly decay all at once.

Fragmentation of macroalgal mats and resuspension of sediment are not solutions but rather management tools to be used with a certain frequency in relation to the eutrophic status of the lagoon. They are tools to apply downstream of the sequence of events set in motion by the causes of eutrophication, which often cannot be solved.

Unfortunately I cannot see any other relatively cheap solutions at the moment to manage the enormous blooms of opportunistic macroalgae that invade coasts and lagoons. I do see a need for a greater common effort by those concerned with these ecological questions: an effort towards solving practical problems and towards applying what we know in synergy with engineers and technicians in a changing environmental context.

\section{References}

1. Hauxwell J, Valiela I (2004) Effects of nutrient loading on shallow seagrass dominated coastal systems: patterns and processes.
2. Raffaelli DG, Raven JA, Poole LJ (1998) Ecological impact of green macroalgal blooms. Oceanography and Marine Biology: an Annual Review 36: 97-125

3. Morand P, Briand X (1996) Excessive growth of macroalgae: a symptom of environmental disturbance. Botan Mar 39: 491-516.

4. Rabalais NN, Turner RE, Wiseman WJ Jr (2002) Gulf of Mexico hypoxia, AKA"The dead zone". Annual Review of Ecology and Systematics 33: 235-263.

5. Chang KH, Amano A, Miller TW, Isobe T, Maneja R, et al. (2009) Pollution Study in Manila Bay: Eutrophication and Its Impact on Plankton Community.

6. Liu D, Keesinga JK, Hec P, Wangd Z, Shia Y, et al. (2013) The world's largest macroalgal bloom in the Yellow Sea, China: Formation and implications. Estuarine, Coastal and Shelf Science 129: 2-10.

7. Thia-Eng C, Paw JN, Guarin FY (1989) The environmental impact of aquaculture and the effects of pollution on coastal aquaculture development in Southeast Asia. Marine Pollution Bulletin 20: 335-343.

8. Primavera $\mathrm{JH}$ (2006) Overcoming the impacts of aquaculture on the coastal zone. Ocean \& Coastal Management 49: 531-545

9. FAO (2009) Environmental impact assessment and monitoring in aquaculture. Requirements, practices, effectiveness and improvements.

10. Lenzi M, Porrello S, Palmieri R (2003) Restoration of the eutrophic Orbetello lagoon (Tyrrhenian Sea, Italy): water quality management. Mar PollutBull 46: 1540-1548.

11. Lenzi M (2010) Resuspension of sediment as a method for managing shallow eutrophic lagoons. J Ecol Nat Environ 2: 220-234.

12. Lenzi M (1992) Experiences for the management of Orbetello Lagoon: eutrophication and fishing. Sci Total Environ suppl 3: 1189-1198.

13. Runca E, Bernstein A, Postma L, Di Silvio G (1996) Control of macroalgae blooms in the Lagoon of Venice. Ocean and Coastal Management 30: 235-257.

14. Lavery P, Bootle S, Vanderklift M (1999) Ecological effects of macroalgal harvesting on beaches in the Peel-Harvey estuary, Western Australia. Estuarine, Coastal and Shelf Science 49: 295-309.

15. De Leo GA, Bartoli M, Naldi M, Viaroli P (2002) A first generation stochastic bioeconomic analysis of algal bloom control in a coastal lagoon (Sacca di Goro, Po River Delta). Marine Ecology 23: 92-100. 